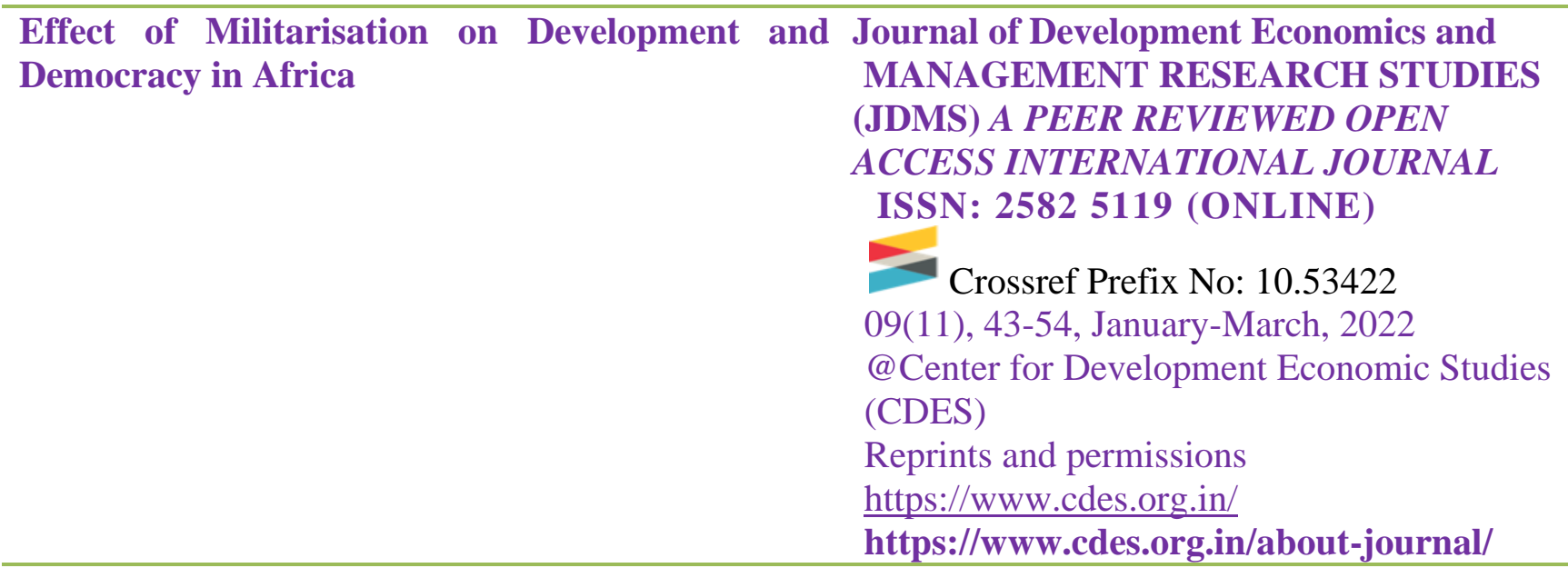

\title{
Effect of Militarisation on Development and Democracy in Africa
}

\author{
Wellington Garikai Bonga ${ }^{1}$ and Darlington Ngoni Mahuku ${ }^{2}$
}

\begin{abstract}
Africa's political democratic and economic growth remains dismal and the prospects for it improving in tandem with the Africa Agenda 2063 are bleak. Africa has plenty of mineral wealth and natural resources yet it remains the least developed region of the Third World. Self-inflicted tragedies galore, derailing the economic progress of the nations. This paper adopted descriptive and analytical methods in its discussion of the effect of militarisation on development and democracy in Africa. The development path of many African nations has no definite pattern to stir the much-required progress. Many policies have been brought forward to guide development with no significant improvement. Some reasons for policy failure may be caused by the way the institutions are being run. The concept of militarisation as brought by this study may add to the impacting factors. Militarisation comes in many forms, and within these forms exist the impacting ones to development and democracy in Africa. This paper offers evidence across Africa that militarypolitical power is detrimental to the positive effect of democracy and hence development. Corruption becomes common where nations are militarised further worsening the development path. Political and economic instability prevails in such nations due to human rights violations caused by militarisation. The study emphasizes the appropriate demilitarisation process for many African nations, establishments of effective civil-military relationships, upholding the rule of law, protecting human rights, avoiding racial and cultural discriminations, institutions autonomy, transparent and collaborative political environment, among other recommendations to ensure attainment of inclusive development and praised democracy. Militarisation is never linked to economic prosperity, rather perpetuates conflict and destruction of states. Post-colonial Africa is in dire need of tangible economic progress, and this is only possible when good policies are effected.
\end{abstract}

Keywords: Africa, Corruption, Democracy, Development, Institutions, Militarism, Militarization, Welfare.

JEL Codes: E02, E61, F54, H53, H56, H73, H77, I31, I38, N47, O15, O43, O55, P26, P48.

\footnotetext{
${ }^{1}$ Department of Banking \& Finance, Great Zimbabwe University.

${ }^{2}$ Department of Peace \& Governance, Bindura University of Science Education.
} 


\section{Introduction}

The concept of militarization is not new in Africa. In the 1970s, the militarisation process became so clear, with the rising of military spending in many countries (Luckham, 1985). Militarization has become a worrying common phenomenon in Africa (Bonga, 2021), and governments of many African nations today are either military or have a military origin. A close connection between governments and the armed forces exists and is traceable in the history of African nations. It is beyond dispute that the military has become a critical player in political and economic developments in post-colonial Africa. The dominance of military aspects in matters of economic development conflict with democratic principles that ensures inclusive development. In support, Lang (1965) submits that, "the ability of the military to dominate and influence government policies and social organization has long been recognized in the post-World War II era."

In contemporary Africa, trends of militarism are observable. Militarism and militarization macro trends threaten the growth and consolidation of democracy (Kraska, 2007; Flores-Maciás, and Zarkin, 2019; Magaloni, 2020). Paradoxically, Robert Dahl hit the nail on the head when he averred that politics is all about resource allocation and distribution. The distribution formula for scarce resources is different for non-military states and militarydominated states. Felice (1998) indicated that militarisation takes resources away from the civilian domain while it mainly benefits those who are in the military. Classical and neoclassical schools of economics consider development in terms of efficient allocation of scarce productive resources to enhance optimal growth, produce and expand various types of goods and services (Coccia, 2019). Scarce resources meant to promote the welfare of the citizenry will mainly benefit the military elite and their supporters. According to Schofield (2007), where militarisation prevails, a state's decision-making process gets distorted, producing less effective strategies to administer and propel economic development and democratic growth in that country as was the case of Nigeria under Sani Abacha. The Abacha case shows that where the military is in power human rights are jeopardised, development is distorted and corruption levels become rampant.

Felice (1998) also noted that fundamental freedoms like freedom of expression, human rights of education, health care and other essential services are affected due to the diversion of resources caused by militarisation. There is no objective of income and resource distribution equality in neo-patrimonial militaristic states in Africa. Human rights abuse is a serious challenge (Bonga, 2021). Arguably militarisation causes institutions to be weak, thereby failing to deliver as expected. Though laws exist, anti-corruption institutions, just like other militarised institutions fail to deliver. According to Momoh (2015), African countries are authoritarian, plagued with corruption and are not able to develop their citizens. In this study, we argue that militarization affects development, impedes democracy growth and consolidation as it promotes and entrenches corruption.

\section{Militarisation}

Militarisation is a disputed model (Bayer et al, 2021; Mutschler and Grebe, 2016; Tilly, 1992; Berghan, 1991), however, as noted by Merryfinch (1981), it is best known by observing its effects. Agbese (1991) submits that issues of military involvement in politics are embedded in the broader dynamic of militarism or militarization. Notably, militarism and militarisation have been conceptual challengers to security (Cock, 1989), and have often been approached primarily as a national phenomenon and as a relationship of state-society and citizen-soldier (Gelot and Sandor, 2019). According to Luckham (1994, 24) "militarisation refers to a multidimensional process through which several elements-such as military coups 
and regimes, authoritarian government, the dominance of patriarchy, powerful military and repressive state apparatuses, war and armed conflict, rising military spending and arms imports, and external military intervention-become dynamically linked, both to each other and more widely to capital accumulation and projects for national and international hegemony. Yet these individual elements have not invariably correlated."

Militarisation is very common in Africa and is erroneously now being seen or considered by many Africans as something normal yet when thorough investigations are made, this is not the case. Militarisation in Zimbabwe can be traced since independence in 1980; South Africa portrays a legacy of close cooperation and affinity between the political and military establishments; due to long history of war, Angola has a government-military closeness; Lesotho remain a quasi-political actor and DR Congo is more dependent upon national and international military forces (Vrey, 2009). As indicated by Bayer et al (2021), militarisation is both tied to the concepts of the military on the one hand and militarism on the other. This, therefore, explains why African armies pose the greatest threat to constitutionalism and democracy on the continent (Mangu, 2005). It is a dynamic and diverse phenomenon, and refers to a particular, authoritarian culture of politics, regardless of the specific character of the regime (Hutchful and Aning, 2001).

Militarisation refers to the placement of ex-military or military personnel in key government positions or public institutions. Army generals were appointed to government ministries under President Yoweri Museveni in Uganda (Aili, 2010). Also, one common method being applied is appointing retired military personnel to public institutions. The placement of military personnel in such key positions is done through patronage networks and not through merit (Bonga, 2021). This is the case in most African countries, and today it seems like a natural event. Moreso, further tracing on the recruitment practice in many African nations have shown that those mostly recruited even in the military are from the ethnicity of the president (for example; Chad, Côte d'Ivoire, Mauritania and Togo). Côte d'Ivoire's Félix Houphouët-Boigny (first president), when in charge reduced the size of the security sector and created a party loyal militia Baoulé dominated. The impact of such policies is severely noticed by civilians who are close to those occupied positions, or to some extent those displaced to give way to military personnel. Occupation of such civilian positions affects the delivery of services by those institutions. Institutions that have been militarised do not efficiently bring forth development as expected (Bonga, Sibanda and Nyoni, 2021). Zimbabwe Defence Forces members were seconded to parastatals including Grain Marketing Board (GMB), National Railways of Zimbabwe (NRZ), National Oil Company of Zimbabwe and Chiadzwa Diamonds, where mismanagement and corruption were witnessed and later led to some organisations downsizing and some closing operations (Vhumba, 2020).

The constabularization of the military has had disastrous consequences as they have a bearing on the quality of democracy in African countries and have undermined citizen security, human rights, security sector reform, and the legal order (Flores-Macías and Zarkin, 2021). Contemporary South Africa, is one African nation marked by a co-existence of both old and new forms of militarism (Cock, 2004). In the country, South Africa, just after independence in 1994, there has been evidence of violence in a new format, commoditisation of security by expansion in the number of private security firms and proliferation of small arms. Small arms in South Africa are highly racialised and it is argued that this may be related to a militarised commencement of citizenship. Despite the emanating concerns that require further cleansing, South Africa is among some nations that have transformed notably from authoritarian to democratic rule, through developing civil-military relationships almost similar to established democracies. 
A common measure for militarisation is the Global Militarization Index (GMI). The GMI shows the relative weight and importance of a nation's military apparatus in comparison to the whole nation. Bonn International Center for Conversion (BICC) has been publishing the GMI since 2003. GMI is funded by Germany's Federal Ministry for Economic Cooperation and Development. It checks the link between militarization and political systems. GMI approach does not only consider the scale of resources allocated to the military but relates them to the wider society (Mutschler and Grebe, 2016). The GMI comprises six indicators, coming from three sub-indices assessing militarisation aspects; (1) expenditures, (2) personnel, and (3) heavy weapons. The Index uses weights allocated to the indicators. The six indicators with their weights are; (1) military expenditures as a percentage of GDP [5], (2) military expenditures in relation to health spending [3], (3) military and paramilitary personnel in relation to the population [4], (4) military reserves in relation to the population [2], (5) military and paramilitary personnel in relation to physicians [2], and (6) heavy weapons in relation to the population [4]. GMI score ranges from 0 (low militarised) to 1,000 (highly militarised). Some authors propose that new data sources offer the opportunity to further develop the Index (Bayer et al, 2021). However, in its current form, some crucial information can be derived through checking the level and dimension of militarisation in world economies. Mutschler and Bales (2018) indicated that a low level of militarization, as measured by GMI, may not automatically link with a high level of freedom of political system - may point to state structures that are weak hence less control by the state.

Angola is one country in Africa that has for years maintained a large army relative to the size of the country, hence heavily militarized as measured by GMI. The country has experienced periods of civil wars; hence the influence of military was for stabilisation. Most notably in Angola was the long fight against Jonas Savimbi militia, who even after losing elections, and signed peace agreements in place, continued to wage disruptive guerrilla war throughout the 1970s and '80s. Nigeria, with the strongest military in West Africa, has a low GMI ranking. Exploring Nigeria on GMI ranking, Mutschler and Grebe (2016) indicated that Nigeria spends just 0.4 per cent of its GDP on the military and for every 1,000 inhabitants there are 0.9 soldiers and 0.3 physicians. Such a low GMI ranking explains why internal conflicts are common in Nigeria. ${ }^{3}$ The country invests so little in its armed forces. Using the GMI ranking, most Sub-Saharan Africa (SSA) countries have a low ranking, except Angola (31), Mauritania (41), Chad (42) and Namibia (44). African nations; Angola, Chad and Mauritania being highly militarised have been observed to have a low human development index. As noted by Mutschler and Grebe (2016) the association between militarisation and human development for these nations may entail disproportionally high spending on the military draining vital resources that were supposed to be used for development.

Exploring the nature of militarisation through relying on the GMI ranking alone for Africa though necessary is not sufficient. Arguably politics in Africa is backed by military forces and/or involves the military in areas where civilians should be having control for effective and collaborative development. Adoption of actions and strategies by authorities that make a country weak or vulnerable is not rational. Promoting militarisation is an irrational decision if it is related to negative development. In support of the fact where militarisation is essential, Nathan (1998) posits that when security is considered closely in terms of the strength of the state and its military, militarisation becomes crucial for stability.

Having noted the above fact, militarisation forms in Africa serve a different purpose. Worth noting is that there is a difference between the security of the state and the security of citizens. Citizen's security mainly requires the attainment of basic human rights and needs, and in cases where they are not met, there is weak governance. A security vacuum arises

\footnotetext{
${ }^{3}$ For example; Niger Delta violence, Gulf of Guinea and Boko Haram terrorist group.
} 
when basic human needs are not met and usually for defensive and offensive purposes the vacuum will be filled by violence. In an attempt to explain this behaviour, realists indicate that political leaders are often faced with endless constraints and few opportunities for cooperation, and have only the ability to do little to escape power politics reality (Antunes and Camisão, 2018). Though demilitarisation may be considered necessary, it should be done with diligence.

According to Nathan (1998) demilitarisation may not resolve the insecurity crisis as it does not effectively deal with the core underlying structural problems. Politicians and their allies may decide to strengthen their 'territory' and benefits by accumulating state resources without concern for the general public. Classical realists opine that because of human nature, which is inherently selfish and egoistic, political leaders are at times greedy and insecure explaining why they guard their positions jealously. The greediness of politicians in Africa has caused them to adopt militarisation as a strategy to protect themselves from possible challengers. This is exemplified by leaders like Yoweri Museveni of Uganda, Paul Biya of Cameroon, Paul Kagame of Rwanda, and the late Robert Mugabe of Zimbabwe just to mention a few.

\section{Development}

It must be noted from the outset that development is a broad term. According to Coccia (2019), "development is a multidimensional process that generates economic, technological, social and institutional change to support the wealth of nations and a comprehensive wellbeing of people in society." Economies are expected to be better with time as measured by development indicators. Development is about freedom, democracy and rule of law (Mahuni, Taru and Bonga, 2020). The development-security nexus has tipped in favour of the military (Fernando, 2020), and is following a related path to that of African countries with military rule. In such countries, like Mali, Chad, Guinea and Sudan among others, the ruling elite and their allies own a large stake in business and commerce.

Notably, the ultimate goal of any economic development process is welfare (Wahyudi, 2020). Africa has major development aspirations in the broader context of a global and continental economic development agenda (Economic Development in Africa Report 2016). Growth in many African states remains volatile, and growth sustenance for a longer period is challenging (AUC, 2018). Africa's development performance indices have lagged persistently behind those of other Third World regions in Latin America and Asia (Ayittey, 2018). Africa is undeniably at the bottom (Mahuni, Taru and Bonga, 2020). The agricultural sector, being the backbone or engine of many African states' development has performed dismally.

Governments through policies effect development. Better policies are usually associated with positive development. If there is a lack or no development, then it entails that the government is failing. Some post-colonial African countries' agricultural output has dropped tremendously to a level where they entirely depend on imports to feed their own citizens. Countries like the Democratic Republic of Congo, Zambia, Sierra Leone, Tanzania and Zimbabwe, being productive to the extent of producing excess to feed other nations in the past, are now struggling to feed themselves. There are many factors that cause nations to suffer negative development. As observed by Kwong and Zimmer (1994), militarization is one of the many factors that negatively impact a country's development. The complexity of the association between militarism and politico-economic growth and development has been investigated (Gunes and Aysan, 2014).

Paradoxically, militarisation affects institutionalism, yet the development and growth of institutions is a pre-condition for economies to grow. Gunes and Aysan (2014) noted that 
social policies in the Middle Eastern and North Africa (MENA) region have been one of the most suffering domains from the overburden of excessive military mobilization. Some countries which include Algeria, Egypt, Libya, Morocco and Tunisia are African countries falling within the MENA region. A popular theorist Rostow (1962) reflected on the preconditions for economic "take off." Rostow states that the development of financial, political and social institutions is a pre-condition for development. To strengthen and enhance development, these pre-conditions must be accompanied by correct social and physical infrastructure and management skills (Khan, 2012). Physical infrastructure has crumbled in Africa due to failure to maintain and repair. Where some infrastructures have been constructed in the post-colonial era, those capital projects have been linked to corruption that is detrimental to any effective and sustainable development. A study by Bonga (2021) indicates that institutions in Africa are militarized to ensure that they operate to the desires of the political regime and elites. With militarised institutions, corruption thrives unabated hence impacting negatively on development.

Momoh (2015) avers those enormous resources are lost internally and externally due to corruption. Resources that were supposed to be used to solve underdevelopment issues in Africa end up enriching a wealthy few and their cohorts. The lack of democratic institutions effectively bars the public from participating in decision-making on political, economic, social and environmental policies (Choi, 2012). Competent professionals are not given the chance to perform duties in public offices. Osei-Hwedie and Osei-Hwedie (2000), noted that politicians in many African countries constantly intervene on how civil servants deliver services and those who resist the dictates of the political elite lose their positions. It is characteristic that such civil servants are replaced by military personnel or their patrons. The militarised institutions are not democratic, thereby limiting the involvement of the public in policy-making. Policies that lack public or stakeholder engagement are likely to fail. In support, Bonga (2016) emphasised that for economic policy to successfully drive the economy stakeholder engagement, communicating policies to the populace, improving institutional and political frameworks are some necessary steps to take.

Arguably militarisation increasing in Africa, there is greater macroeconomic uncertainty arising from the way the economies are being run. According to Kaya (2018), uncertainty creates negative externalities, due to its negative correlation with the business cycle, and it intensifies recession impact and aid risks build-up in good times. In support, Bonga (2019) argued that "to create a good economic climate, to attract investment and boost confidence in the economy, policymakers should dwell on reducing macroeconomic uncertainty." In tandem with the above-raised argument, if any meaningful development is to take root in Africa, the militarisation of public institutions and patronage relations must be discouraged.

\section{Democracy}

Democracy's journey in Africa, being impacted by many factors, deviates from the smooth path of democratic growth and consolidation (Bailie, 2018). The lack of democracy in many African nations for many years contributed to the delaying of benefits of integration (Mahuni, Taru and Bonga, 2020). It is a fact that there is a negative correlation between militarisation and the growth and consolidation of democracy. Birchler (2012) posits that democracy has a progressive impact on GDP growth but only if there is no military rule. It is therefore not surprising that militarised governance constitutes the central impeding issue challenging the advancement of African development and democracy (Aradau, 2004). Currently, democratisation across Africa is incomplete; while it is obtaining in a few countries like Botswana, South Africa and Mauritius just to mention a few countries in 
Africa, it has halted in some countries and regressed in other countries. The post-colonial leadership, with a few exceptions, established defective political and economic systems in which enormous power was concentrated in the hands of the state and ultimately one individual (Ayittey, 2018).

Table 1 below shows the democracy index of African nations published by The Economist Intelligence Unit (EIU) in 2019. Five sets of criteria define the index: electoral process and pluralism, civil liberties, the functioning of government, political participation, and political culture.

Table 1: Democracy Index of African Countries

\begin{tabular}{|c|c|c|c|c|c|c|c|c|c|c|c|}
\hline 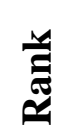 & $\vec{\Xi}$ & 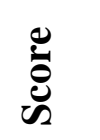 & 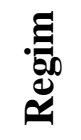 & 茯 & 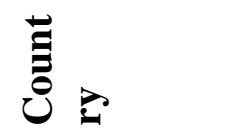 & 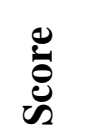 & 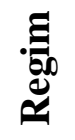 & 泀 & $\stackrel{\vec{\Xi}}{\overrightarrow{0}}$ & : & ב \\
\hline 18 & Mauritius & 8.22 & $\mathrm{D}$ & 99 & Uganda & 5.02 & $\mathrm{H}$ & 131 & Comoros & 3.15 & A \\
\hline 29 & Botswana & 7.81 & FD & 100 & Mali & 4.92 & $\mathrm{H}$ & 132 & eSwatini & 3.14 & $\mathrm{~A}$ \\
\hline 30 & Cabo Verde & 7.78 & FD & 102 & Sierra Leone & 4.86 & $\mathrm{H}$ & 132 & Guinea & 3.14 & $\mathrm{~A}$ \\
\hline 40 & South Africa & 7.24 & FD & 107 & Gambia & 4.33 & $\mathrm{H}$ & 134 & Congo & 3.11 & A \\
\hline 53 & Tunisia & 6.72 & FD & 109 & Nigeria & 4.12 & $\mathrm{H}$ & 137 & Egypt & 3.06 & $\mathrm{~A}$ \\
\hline 55 & Ghana & 6.63 & FD & 111 & Côte d'Ivoire & 4.05 & $\mathrm{H}$ & 141 & Cameroon & 2.85 & $\mathrm{~A}$ \\
\hline 60 & Lesotho & 6.54 & FD & 112 & Burkina Faso & 4.04 & $\mathrm{H}$ & 144 & Djibouti & 2.77 & A \\
\hline 65 & Namibia & 6.43 & FD & 113 & Algeria & 4.01 & $\mathrm{H}$ & 147 & Sudan & 2.7 & $\mathrm{~A}$ \\
\hline 82 & Senegal & 5.81 & $\mathrm{H}$ & 116 & Mauritania & 3.92 & $\mathrm{~A}$ & 148 & $\begin{array}{l}\text { Guinea- } \\
\text { Bissau }\end{array}$ & 2.63 & $\mathrm{~A}$ \\
\hline 85 & Madagascar & 5.64 & $\mathrm{H}$ & 119 & Angola & 3.72 & A & 152 & Eritrea & 2.37 & $\mathrm{~A}$ \\
\hline 87 & Malawi & 5.5 & $\mathrm{H}$ & 120 & Mozambique & 3.65 & $\mathrm{~A}$ & 154 & Burundi & 2.15 & $\mathrm{~A}$ \\
\hline 88 & Liberia & 5.45 & $\mathrm{H}$ & 121 & Gabon & 3.61 & A & 156 & Libya & 2.02 & A \\
\hline 94 & Kenya & 5.18 & $\mathrm{H}$ & 125 & Ethiopia & 3.44 & $\mathrm{~A}$ & 161 & Eq. Guinea & 1.92 & $\mathrm{~A}$ \\
\hline 95 & Tanzania & 5.16 & $\mathrm{H}$ & 126 & Togo & 3.3 & A & 163 & Chad & 1.61 & A \\
\hline 96 & Morocco & 5.1 & $\mathrm{H}$ & 127 & Niger & 3.29 & A & 165 & $\begin{array}{l}\text { Cent. } \\
\text { African Rep. }\end{array}$ & 1.32 & A \\
\hline 97 & Benin & 5.09 & $\mathrm{H}$ & 129 & Rwanda & 3.16 & $\mathrm{~A}$ & 166 & DRC & 1.13 & A \\
\hline 97 & Zambia & 5.09 & $\mathrm{H}$ & 129 & Zimbabwe & 3.16 & A & & & & \\
\hline
\end{tabular}

From Table 1 above, only Mauritius which ranks 18 in the world has full democracy. Full democracies are the ideal regime; it refers to nations in which basic political freedoms and civil liberties are respected by the government, the people and the culture (Institute for Economics \& Peace (IEP), 2021). 7 countries have been ranked as "flawed democracies, 17 hybrid and 25 classified as authoritarian. Seychelles, South Sudan, Somalia, and Sao Tome and Principe have been excluded by the report, however, with the missing information, they belong to the same as other African countries. In the past decade, there has been a weakening of the electoral process and political pluralism witnessed in most sub-Saharan African nations, and this has led to such regimes.

For post-colonial Africa, military rule dominated for years, receded and is now becoming popular again. It must be pointed out that years of military rule have nurtured a 
tyrannical political atmosphere that disobeyed democratic principles, exploited public resources, and have disrespected human rights and the rule of law (Choi, 2012). Politics with military influence takes another shape. According to Demir (2005), political and military class segregation from the rest gives them the power to resist criticisms concerning their conduct as was the case with the Sani Abacha regime in Nigeria and other countries. In some cases, when politicians are not in sync with military interests, coups occur. Luckham (1994) observed that the intervention by the military in politics is additive, and is also linked to the relative size of the military.

Where a culture of military intervention is strong, coups are always likely to happen, implying that the military determines who rules the government at a particular time. No significant changes have been so far observed in those African nations where coups have occurred. Sudan, Nigeria, Guinea, Mali, Niger, Burkina Faso, Chad, Comoros, Ghana, Sierra Leone, and Zimbabwe are some African nations that have witnessed coups years after their independence. Some coups failed while others were successful. Africa continent is above in statistics for coups in relation to other continents. Countries in Africa have conditions common for coups, being poverty, poor economic performance, income inequality and corruption. However, some coups may have some reasons not so clear and common with other nations, country-specific. For recent (2021) coups, a period of democratic backsliding and policy failure led to a coup in Mali; in Chad, the need to secure a continuation of elite power was the cause; and the need to end an unpopular president to go for a third term led to a coup in Guinea.

It seems the same type of abandoned leadership is replaced by a similar type when a coup occurs. Institutions are not changing with the change in leadership. The institutions remain weak. A mercantilism approach is experienced in Africa, where politics determines economics. The inclusion of militarism in the welfare state literature necessitates a politicaleconomic approach, which mainly deals with the implications of political power on politicaleconomic outcomes (Holden, 2005). Notably, strong democratic institutions that promote good governance are an essential prerequisite for the growth of democracy and sustainable economic development.

\section{Corruption}

Corruption is a scourge and an impediment to the development of all countries. Corruption undermines public confidence in the institutions of the state. It particularly impedes the progress of countries in transition as there is misappropriation of the muchneeded capital away from the state (Togarev, 2010; Maguchu, 2011). Baker (2016) noted with concern that defence spending in the continent was rising, and there exists no better tracking on how the monies were spent within the sector. In Burkina Faso, Mali, and Niger, 2020 judicial developments highlighted a misappropriation trend of resources allocated to defence and security (Padonou, 2021). Where militarisation prevails, corruption is worse and becomes difficult to address due to weakened institutions.

Corruption is rampant in Africa. Despite exhibiting potential, these states in Africa would not develop much given alarming corruption levels (Mahuni, Taru and Bonga, 2020). For Nigeria it is now the way of life, in Sierra Leone, it has become a culture and in Sudan, it is the fifth factor of production (Osei-Hwedie and Osei-Hwedie, 2000). Adding on the effects of corruption, Zepeda, Rosen and Rodrigues (2020) contend that corruption undermines democratic institutions, hinders economic development, and contributes to government instability. The eight recognized regional blocs by the African Union (AU) has corruption reduction as one of the agenda, indicating the need to address corruption for a better Africa (Bonga, 2021). AU recognize as regional blocs; Arab Maghreb Union (AMU), East African 
Community (EAC), Economic Community of Central African States (ECCAS), InterGovernmental Authority on Development (IGAD), Economic Community of West African States (ECOWAS), Community of the Sahel-Saharan States (CEN-SAD), Common Market of Eastern and Southern Africa (COMESA), and; the Southern African Development Community (SADC).

It is a challenge for African leaders to combat corruption as they seem to lack the political will to deal with it, and therefore the efforts and commitments of African leaders remain questionable (Momoh, 2015). The government under Kagame, for Rwanda, has been known for its intolerance towards corruption, thereby taking the nation among the list of least corrupt countries in Africa after Botswana and Seychelles, as provided by Transparency International. All this has encouraged development, and worth noting that Rwanda should maintain its momentum. South Africa is another lowly ranked in terms of corruption, however, corruption is still deeply entrenched, with big people implicated in many cases.

For many states in Africa, corruption remains to be dealt with. Anti-corruption laws exist in the countries, same as institutions to deal with corruption, but their effectiveness to bring down grand corruption is questionable as well. Grand corruption has had a lot of damage to African economies because most are done by big people in the society (Bonga, 2021a). The situation has been exacerbated by the fact that institutions to deal with corruption, just like other institutions, are militarised hence they are weak and unable to efficiently perform duties in a fair manner. The military presence inhibits civilians from partaking in their duties effectively and professionally. Apart from paralysing institutions, some institutions have been formed by politicians themselves to disguise their ruthless leadership (Bonga, Sibanda and Nyoni, 2021). Powerful politicians paralyse the anticorruption institutions thereby rendering them submissive to the regime (Bonga, 2021). The institutions exist to protect the elites; corrupt activities related to the ruling elites are never dealt with, or are lightly addressed. Leadership in many African states have developed their own world in which they benefit more at the expense of the citizens [ibid].

\section{Conclusion and Policy Recommendations}

Militarisation has been found to be part of the history of many African nations. There are various forms of militarisation, some of which have greater effects on the development path of the nations. Militarisation is used by politicians to extend their rule for their benefit including cronies. African nations have suffered development challenges at the expense of its leadership being military and/or having military support/origin. Africa can be described using the revisionist conception that the states have created more issues than they can solve. The majority of the population in Africa suffer more than they benefit from the state. The core values; security, freedom, order, justice and welfare are poorly defined for Africa. Due to the economic disorders caused by militarisation, the continent of Africa remains characterised by violence, instability and poverty.

For progress, countries have to balance their legitimate security obligations and development needs through strategic demilitarization. Reintroducing multiparty politics is a wonder to correct what has been damaged. As noted by Schofield (2007), diluting military influence in the decision-making process will guarantee the attainment of better levels of development. When institutions become less militarized, they will be able to perform their duties with autonomy. Democracy promotes economic development. African nations should work on strengthening their institutions. Choi (2012) supported this idea by indicating that strong democratic institutions promoting good governance are sustainable development crucial prerequisites. 
The military, as a sector of the economy, has a responsibility to institutionalize an ethical and accountable culture to build and maintain social trust and respect. The army should be professional. The professional army must maintain relationships with all key security actors to perform its duties effectively (Ouédraogo, 2014). Military justice systems must be made compatible with standards concerning human rights. A transparent and collaborative political environment between military and civilian is required and its mandate is to be effectively followed. Also necessary are international community partnerships to strengthen the way economies function in acceptable ways.

Addressing appropriately and effectively issues of militarisation in Africa will be a great step in dealing with one of the internal factors affecting development in Africa. For better results more should be done in collaboration utilizing existing regional blocs as well as an integrated Africa.

\section{References}

1. Agbese, P.O. (1991). Demilitarization and Prospects for Democracy in Nigeria. Bulletin of Peace Proposals, 22(3), pp. 315-327. DOI: 10.1177/096701069102200309.

2. Aili, M.T. (2010). Museveni's Uganda: Paradoxes of power in a hybrid regime. Lynne Rienner Publishers, Boulder.

3. Antunes, S and Camisão, I. (2018). Introducing Realism in International Relations Theory. E-International Relations. https://www.e-ir.info/2018/02/27/introducingrealism-in-international-relations-theory/

4. Aradau, C. (2004). 'Security and the Democratic Scene: Desecuritization and Emancipation'. Journal of International Relations and Development 7(4), 388-413.

5. AUC/OECD (2018), Africa's Development Dynamics 2018: Growth, Jobs and Inequalities, AUC, Addis Ababa/OECD Publishing, Paris. https://doi.org/10.1787/9789264302501-en

6. Ayittey, G.B.N. (2018). Why Africa is Poor. Lome, Africa, pp: 01-16.

7. Bailie, C. (2018). The African Military in a Democratic Age. Conflict Trends 2. https://www.accord.org.za/conflict-trends/the-african-military-in-a-democratic-age/

8. Baker, A. (2016). Corruption in Military Defense Spending Could Be Behind Rise in Africa Terror Attacks. Time, USA. https://time.com/4184472/military-corruption-africaterror-attacks/

9. Bayer, M., Alberth, R., Hauk, S., and Mutschler, M. M. (2021). Global Militarisation Index: presentation, codebook and reflexion. (BICC Working Paper, 3/2021). Bonn: Bonn International Center for Conversion (BICC). https://nbnresolving.org/urn:nbn:de:0168-ssoar-74494-9

10. Berghan, V. (1981). Militarism, Cambridge: Cambridge University Press.

11. Birchler, K. (2012). The effect of military political power on economic development in de jure democracies. Center for Comparative and International Studies (CIS), Working Paper No. 76.

12. Bonga, W.G. (2016). An Explanatory Analysis of Components Constituting Economic Policy Success in Zimbabwe. Dynamic Research Journals' Journal of Economics and Finance (DRJ-JEF), Volume 1, Issue 1, pp: 07-12.

13. Bonga, W.G. (2019). Measuring Macroeconomic Uncertainty in Zimbabwe. Munich Personal RePEc Archive (MPRA) Paper No. 94759.

14. Bonga, W.G. (2021). Exploring the Impact of Neopatrimonialism Dominance in Africa. Dynamic Research Journals' Journal of Economics and Finance (DRJ-JEF), Volume 6, Issue 1, pp: 17-23. 
15. Bonga, W.G. (2021a). Corruption Prevalence in SADC Regional Bloc. Quest Journals' Journal of Research in Humanities and Social Science, Vol. 9(1), pp: 08-16.

16. Bonga, W.G., Sibanda, Z.B., and Nyoni, T. (2021). The 'New Normal' Concept Critique. Journal of Development Economics and Management Research Studies (JDMS), 08(10), 16-28.

17. Choi, L. (2012). Militarized development is always untenable. Burma, Social Watch: 8283.

18. Coccia, M. (2019). Theories of Development. In, Farazmand, A. (ed.), Global Encyclopedia of Public Administration, Public Policy, and Governance, https://doi.org/10.1007/978-3-319-31816-5_939-1

19. Cock, J. (1989). 'Keeping the Fires Burning: Militarisation and the Politics of Gender in South Africa'. Review of African Political Economy 45/46, 50-64.

20. Cock, J. (2004). Rethinking Militarism in Post-Apartheid South Africa. Crisis States Programme Working Paper No.43, 1-17.

21. Demir, F. (2005). Militarization of the Market and Rent-Seeking Coalitions in Turkey. Development and Change 36(4): 667-690.

22. Economic Development in Africa Report 2016.

23. Felice, W.F. (1998). Militarism and Human Rights. International Affairs, 74(1): 25-40.

24. Fernando, N. (2020). Strategic Demilitarization in Sri Lanka: Paradoxes and Trajectories. Journal of International Affairs, Vol. 73, No. 2.

25. Flores-Maciás, G.A. and Zarkin, J. (2019). "The Militarization of Law Enforcement: Evidence from Latin America," Perspectives on Politics: 1-20.

26. Flores-Macías, G.A., and Zarkin, J. (2021). The Militarization of Law Enforcement: Evidence from Latin America. Perspectives on Politics, Volume 19, Issue 2, pp. 519 538, DOI: https://doi.org/10.1017/S1537592719003906

27. Gelot, L and Sandor, A. (2019). African security and global militarism. Conflict, Security \& Development, 19:6, 521-542, DOI: 10.1080/14678802.2019.1688959

28. Gunes, E and Aysan, M.F. (2014). Militarism and Welfare Distribution in the Middle East and North Africa. Afro Eurasian Studies Journal, Volume 3, Issue 2, pp. 68-91.

29. Holden, C., 2005. Social Policy and Political Economy: A Tale of (at least) Two Disciplines. Social Policy and Society, 4(02), pp. 173-182.

30. Hutchful, E and Aning, K. (2001). Militarisation and State Reconstruction in Africa: The West African Case. A Journal of Constitutional Development, pp. 01-23.

31. Institute for Economics \& Peace. (2021). Global Peace Index 2021: Measuring Peace in a Complex World, Sydney. Available from: http://visionofhumanity.org/reports (accessed 12 October 2021).

32. Kaya, O. (2018). Economic policy uncertainty in Europe: Detrimental to capital markets and bank lending. Deutsche Bank Research, Germany.

33. Khan, S. (2012). The Military and Economic Development in Pakistan. Working Paper Series Number 291: 01-13.

34. Kraska, P.B. (2007). "Militarization and Policing: Its Relevance to 21 st Century Police," Policing 1, no. 4: 501-13;

35. Kwong, J and Zimmer, Z, (1995). Militarization and social development in the Third World. Journal of Sociology, 31(1): 64-81. DOI: 10.1177/144078339503100105

36. Lang, K. (1965) "Military Sociology," Current Sociology 13, no. 1: 1-26.

37. Luckham, R. (1985). Militarization in Africa: Militarization and Conflict in Africa. Bulletin of Peace Proposals. 17(3-4):447-454. doi:10.1177/096701068601700332

38. Luckham, R. 1994, 'The Military, Militarization and Democratization in Africa: A Survey of Literature and Issues,' African Studies Review, vol. 37 no. 2, pp. 13-75. 
39. Magaloni, B. and Rodriguez, L. (2020). "Institutionalized Police Brutality: Torture, the Militarization of Security, and the Reform of Inquisitorial Criminal Justice in Mexico," American Political Science Review 114, no. 4: 1013-34.

40. Maguchu, P.S (2011). "Analysis of Political Corruption Trends in Transitional States." Masters Thesis, Faculty of Law, University of the Western Cape.

41. Mahuni, K., Taru, J and Bonga, W.G (2020). "Africa's Incomplete Cycles of Development." Peter Lang International Academic Publishers.

42. Mangu, André Mbata B. (2005) Challenges to Constitutionalism and Democratic Consolidation in Africa. Politeia, 24 (3), pp. 315-334.

43. Merryfinch, L. (1981). 'Militarism', in Wendy, C. (ed.), Loaded Questions: Women in the Militaries, Amsterdam: Transnational Institute, p.9.

44. Momoh, Z. (2015). Corruption and Governance in Africa. The International Academic Conference for Sub-Sahara African Transformation \& Development. Vol. 3, No.6.

45. Mutschler, M.M. and Grebe, J. (2016). The Global Militarisation Index. Bonn International Center for Conversion (BICC).

46. Mutschler, M.M., and Bales, M. (2018). Global Militarization Index 2018. Bonn International Center for Conversion $\mathrm{GmbH}$.

47. Nathan, L. (1998). Good Governance, Security and Disarmament in Africa. Afr.j.polit. sci. (1998), Vol. 3 No. 2, 69-79.

48. Osei-Hwedie, B.Z., Osei-Hwedie, K. (2000). The Political, Economic, and Cultural Bases of Corruption in Africa. In: Hope, K.R., Chikulo, B.C. (eds) Corruption and Development in Africa. Palgrave Macmillan, London. https://doi.org/10.1057/9780333982440_3

49. Ouédraogo, E. (2014). Advancing Military Professionalism in Africa. Africa Center for Strategic Studies, Research Paper No. 6.

50. Padonou, O. (2021). Armed forces in the Sahel face challenges of transparency and corruption. iD4D Sustainable Development News. https://ideas4development.org/en/armed-forces-sahel-challenge-transparency-corruption/

51. Rostow, W., 1960, The Stages of Economic Growth: A Non-Communist Manifesto. Cambridge: Cambridge University Press.

52. Schofield J. (2007) Militarization and War. In: Militarization and War. Initiatives in Strategic Studies: Issues and Policies. Palgrave Macmillan, New York. https://doi.org/10.1007/978-1-137-07719-6_2

53. Tilly, C. (1992). 'War and the International System 1900 - 1992', New York: New School for Social Research.

54. Togarev, T. (2010). Building Integrity and Reducing Corruption in Defence: A Compendium of Best Practices. Geneva Centre for the Democratic Control of Armed Forces.

55. Very, F. (2009). Strategic culture of the Southern African Development Community: Militarised pathways to security? African Journal on Conflict Resolution, No. 1.

56. Vhumba, G. (2020). The Zimbabwe Defence Force`s Military Operations other than War (MOOTW) in The Post-2000 Period. Doctoral Thesis, University of South Africa.

57. Wahyudi, W. (2020). "The Relationship between Government Spending and Economic Growth Revisited," International Journal of Economics and Financial Issues, 10(6), 8488. https://doi.org/10.32479/ijefi.10614

58. Zepeda, R., Rosen, J.D., and Rodrigues, T. (2020). Militarization, Organized Crime, and Democratic Challenges in Mexico. Pensamiento Propio, 51: 233-256. 